\title{
Study on Teaching Reform of Basic College Computer Courses in Less Class Hours
}

\author{
Liu Qin \\ Department of Information Science and Technology, East China University of Political Science \\ and Law, Shanghai 200042, China \\ email: liuqin@ecupl.edu.cn
}

\begin{abstract}
The basic college computer education is generally facing with the contradiction between reductions in class hours and increase in contents. This paper puts forth some optional solutions aiming at these features of basic computer courses. It has been found that these solutions are very effective with a certain popularizing significance.
\end{abstract}

Keywords: Teaching reform, Computer courses, Less class hours.

\section{Introduction}

At present, most of colleges have set up some popularizing courses named the Fundamentals of Computer Application, the Basic Computer Applications and the Introduction to Computers, which are related to computer science. Each of the colleges has worked out different teaching program and contents according to their own conditions.

Our school is a traditional college of liberal arts, and our students are mostly engaged in the work related to laws after graduation. So our basic computer course teaching focuses on utilization and application of basic computer courses, and the teaching contents are in a bid to be extensive and new, mainly including basic computer theory (micro-electronic and computer technology, data communication technology, multimedia technology, network technique, database technique and the the foundation of programming design) and practical software operations (Windows, Office, Photoshop, Flash, Dreamweaver, Access, Visual Basic, etc.). More basic contents are required to be taught, but total class hours of the basic courses are reduced in actual teaching[1]. So, we propose some countermeasures based on our teaching experience over years for these basic courses with new and extensive contents but less class hours.

\section{Grouping teaching}

The computer technology education is popularized in elementary and secondary schools in many regions at present in China. Through study, students understand and master basic knowledge and skills of computer technology, cultivate their own interests in computer, and have learned some basic operating skills, especially they are more familiar with application of operating system and office software. However, it is also found the level of computer education is very different in these middle and primary schools in regions with their different material conditions, and some students from these regions have never learned the computer, and even don't know how to start up a computer before they enter colleges. To such complex target objects, we adopt the grouping teaching approach[2], that is, the students are grouped and taught by test, and those who are lack of knowledge of computer science are required to learn the Fundamentals 
of Information Technology and Office Application which deals with the applications of operating system (Windows) and Office software. By this way, we don't introduce Windows and Office any more or only describe them very simply when teaching the basic computer courses to all students, so as to save more precious class hours for these courses.

\section{Textbook construction}

A good teaching material is not only a helper of teachers, but also provides a help to students for review and self-study after class. Due to less class hours, partial contents are inevitably required to practice after class. So the teaching materials, especially experimental books involved in software operation should provide a certain quantity of exercises as well as their operating steps or prompts besides detailed introduction to software functions. In this way, even though teachers don't teach textbooks or only introduce simply them in class, students can teach themselves based on the textbooks. In addition, students are unable to buy all books involved in more software required in teaching programmes. In this case, all teachers in our teaching \& research group spent more two years and prepared several targeted experimental teaching materials. These teaching materials (textbooks) are well compiled by the pictures and their accompanying essays, where there are more detailed referencing steps or operating descriptions for the problems and typical questions. By this way, it provides a helper to the self-learning of the students who have weak partial basic computer knowledge and are unable to keep pace with teaching progress.

\section{Diversified teaching forms}

It may affect the teaching quality directly whether the teaching form is appropriate [3]. The basic computer courses are characterized by heavy teaching task and complex target objects but less class hours. Thus, it is important how to apply appropriate teaching forms.

Alternate teaching of basic theory and software operation

There is more extensive deep and difficult knowledge of basic computer theory as well as relatively boring contents based on the teaching programme. The teaching effect is affected certainly if all knowledge is taught simultaneously. If all of the knowledge is taught together with the software operations, the basic theoretical knowledge is more difficult to be integrated with software operation, so that the basic computer courses are not taught smoothly. By our practical exploration, the partial basic theoretical knowledge closely related to software operation is taught together with related software operations, but those unrelated to software operations are explained together finally, for example, network techniques and webpage making can be taught together, whereas micro-electronic and data communication technology can be taught together finally. Practice has proved that this way can make the class vivid to a certain extent, and let students understand the computer knowledge system fully.

"Micro-lesson-style" teaching management

At first, we divide each basic computer course into several inter-independent knowledge points (10 minutes at least). For example, in Flash teaching, we divided the course into several independent knowledge points such as basic motion, frame-by-frame motion and shape tweens. For each knowledge point is matched with such sections as video description, matters needing attention to operations, demonstration by examples, practices after class, and knowledge extending. The students are required to pre-view the video description before class, so that they 
can attend class with questions; after class, they are required to study further knowledge besides completing practices.

Cycling arrangement for computer practice

As the basic computer courses are involved in many software with less class hours, students often forget the previous knowledge after learning the latter software knowledge, so that they seem to have not learned the knowledge they learned before. For this case, based on famous Ebbinghaus forgetting curve [4] and our practical situation, we arranged the computer operations that we taught before two weeks when arranging the new computer practice each time. By this way, the teachers' rework can be reduced feasibly.

Improving experimental environment and fostering students' self-study ability

In the teaching of basic computer courses, there are often too many contents to be taught and less time for computer practice in class. It is indeed difficult for the students who are poor in basic computer knowledge but bad in the economic condition when they have to stand the cost for computer practice after class. In order to address this problem, the staff members in computer rooms open up a computer room but no Internet service provided only for students' computer practices related to the basic computer courses. So this meets the computer-practicing requirement of the students from poor families, and promotes their self-learning ability.

Combining with law major and developing new courses

Nowadays, people are living at the age of legal environment. Thus, we develop not only above tradition computer-related basic courses, but also some courses with legal characteristics, such as the Computer Network Crimes and Electronic Evidences Taking, the Electronic Law Business and the Intellectual Property Protection for Software. Moreover, these courses arouse students' enthusiasm in computer learning.

\section{Conclusions}

Through the concerted effort of all teachers in our teaching and research office, we ranked top in teaching evaluation grades in the courses of the same kind school-wide and won several teaching achievement prizes. In addition, we kept top three for our students' performance in annual grade examination among colleges in Shanghai.

We should further improve some aspects in our computer teaching though we have made some progress. For example, in students grouping teaching, how teachers bring into full play the instruction role in a more humanized way in relieving few students' fear to computer learning, so that they set up confidence and interest in computer learning. In computer practices, how to make use of the contents related to students' majors to arrange them for computer practices. In questions and answer, how to set more question-answering time online. In addition, the micro-lesson construction should be further improved, especially computer maintenance [5]. In short, we should go with the times constantly, and improve and update teaching contents and forms to let students not only acquire more knowledge but also improve their ability accordingly.

\section{References}

[1] Gao Lin: Teaching reform and innovation of computer basic education in the new period. Computer Education. No.11(2012), p.98-103

[2] Yang Yi-gao, Zhang Wei-li: On college computer education modules. Journal of Hebei Normal University. Vol 14 No.5(2012), p.95-96 
[3] Zheng Li: Reflections on the teaching of computer basic education. Computer Education. No.1(2014), p.101-103

[4] Pan Mao-yuan, Wu Lin-qing, Huang Jing-han, in :New higher education (second edition), edited by Beijing Normal University Publising, Beijing, China(2009).

[5] Zhan De-chen, Nie Lan-shun, Xu Xiao-fei: College Computer education. China University Teaching. No.4 (2011), p.15-20 